\title{
Psychological exhaustion of radiological nursing workers in nuclear medicine services
}

\author{
Desgaste psíquico dos trabalhadores de enfermagem radiológica em serviços de medicina nuclear \\ Desgaste psíquico de los trabajadores de enfermería radiológica en servicios de medicina nuclear
}

\section{Juliana Almeida Coelho de Melo' ORCID: 0000-0003-2217-9649}

Francine Lima Gelbcke" ORCID: 0000-0003-3742-5814

Felipa Rafaela Amadigi" ORCID: 0000-0003-1480-1231

Andrea Huhn'

ORCID: 0000-0002-4348-9374

Charlene da Silva'

ORCID: 0000-0003-0761-4358

Gerusa Ribeiro' ORCID: 0000-0003-3188-8017

'Instituto Federal de Educação, Ciência e Tecnologia de Santa Catarina. Florianópolis, Santa Catarina, Brazil. "Universidade Federal de Santa Catarina. Florianópolis, Santa Catarina, Brazil.

How to cite this article: Melo JAC, Gelbcke FL, Amadigi FR, Huhn A, Silva C, Ribeiro G. Psychological exhaustion of radiological nursing workers in nuclear medicine services. Rev Bras Enferm. 2020;73(Suppl 1):e20200169. doi: http://dx.doi.org/10.1590/0034-7167-2020-0169

Corresponding author:

Juliana Almeida Coelho de Melo

E-mail: julianac@ifsc.edu.br

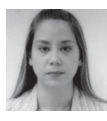

EDITOR IN CHIEF: Antonio José de Almeida Filho ASSOCIATE EDITOR: Álvaro Sousa

Submission: 05-01-2020

Approval: 09-17-2020

\section{ABSTRACT}

Objective: to analyze the psychic exhaustion experienced by nursing workers in nuclear medicine services. Method: a qualitative study that used the methodological assumptions of Psychodynamics of Work. The study was 12 nursing workers from two nuclear medicine services. For data analysis and treatment, Collective Subject Discourse was used with help of the software QualiQuantSoft. Results: the psychic exhaustion experienced by nursing workers originates mainly from work organization, conditions and relationships, and can compromise the quality of care provided and workers' quality of life. Psychic exhaustion is manifested by stress, tiredness and apathy in activities performed outside the work environment. Final considerations: individuals who work also live socially, so psychic health maintenance will impact on work activity. The service should include workers in the organization and offer spaces for dialogue and collective support.

Descriptors: Occupational Health; Nuclear Medicine; Burnout, Professional; Radiologic and Imaging Nursing; Workers.

\section{RESUMO}

Objetivo: analisar os desgastes psíquicos vivenciados por trabalhadores de enfermagem em serviços de medicina nuclear. Método: estudo qualitativo que utilizou os pressupostos metodológicos da Psicodinâmica do Trabalho. Fizeram parte da pesquisa 12 trabalhadores de enfermagem de dois serviços de medicina nuclear. Para análise e tratamento dos dados, utilizou-se o Discurso do Sujeito Coletivo, com auxílio do software QualiQuantSoft . Resultados: os desgastes psíquicos vivenciados por trabalhadores de enfermagem se originam, principalmente, na organização, condições e relações do trabalho, podendo comprometer a qualidade da assistência prestada e a qualidade de vida dos trabalhadores. Os degastes psíquicos são manifestados pelo estresse, cansaço e apatia nas atividades realizadas fora do ambiente de trabalho. Considerações finais: o sujeito que trabalha também vive socialmente, portanto, a manutenção da saúde psíquica impactará na atividade laboral. O serviço deve incluir o trabalhador na organização e ofertar espaços de diálogo e suporte coletivo.

Descritores: Saúde do Trabalhador; Medicina Nuclear; Desgaste Profissional; Enfermagem Radiológica; Trabalhadores.

\section{RESUMEN}

Objetivo: analizar el desgaste psicológico que experimentan los trabajadores de enfermería en los servicios de medicina nuclear. Método: estudio cualitativo que utilizó los supuestos metodológicos de la Psicodinámica del Trabajo. El estudio incluyó a 12 trabajadores de enfermería de dos servicios de medicina nuclear. Para el análisis y tratamiento de los datos se utilizó el Discurso Colectivo del Sujeto, con la ayuda del software QualiQuantSoft?. Resultados: el desgaste psicológico que experimentan los trabajadores de enfermería se origina principalmente en la organización, condiciones y relaciones de trabajo, que pueden comprometer la calidad de la atención brindada y la calidad de vida de los trabajadores. Las degeneraciones psíquicas se manifiestan por el estrés, el cansancio y la apatía en las actividades realizadas fuera del entorno laboral. Consideraciones finales: la persona que trabaja también vive socialmente, por tanto, el mantenimiento de la salud psíquica repercutirá en la actividad laboral. El servicio debe incluir al trabajador en la organización y ofrecer espacios de diálogo y apoyo colectivo.

Descriptores: Salud Laboral; Medicina Nuclear; Agotamiento Profesional; Enfermería Radiológica y de Imágenes; Trabajadores. 


\section{INTRODUCTION}

Work is much more than performing, fulfilling and repeating tasks or selling the workforce in exchange for remuneration. For Dejours, it is through work that individuals' social bonds are built ${ }^{(1)}$. People build part of their identity, provide their own and family support and conceive who they are in the society of which they are part ${ }^{(2)}$.

Contemporary work goes through a series of significant changes resulting from the expansion of capitalism, mainly regarding the mode of production, advent and incorporation of new technologies that, consequently, drive changes in work division, organization and management ${ }^{(3)}$. These changes are reflected in health service workers, as, on the one hand, the incorporation of new techniques and technologies has brought advances to the sector, on the other, they require constant technical training from workers, increased responsibilities with the complexity of tasks and intensification of the work pace ${ }^{(2-3)}$.

In this reality, nursing workers are exposed to different workloads, including physical, biological, chemical, physiological, mechanical loads and also psychological loads ${ }^{(4)}$. These workloads directly affect working conditions, which can lead to physical and psychological exhaustion, which often take time to be noticed and agreed upon by workers themselves ${ }^{(5)}$. Among the various health services, nuclear medicine services (NMS) stand out. For the Ministry of Health ${ }^{(6)}$, NMS have a high complexity service characteristic, involving high technology and high cost.

In addition to workloads associated with the nursing activity in NMS, these professionals are exposed to the physical load of constant exposure to ionizing radiation. Users, who are objects of nursing work, become the emitter of ionizing radiation when they receive radiopharmaceutical agent administration - radioactive substance added to a drug for use in therapy or medical diagnosis ${ }^{(7)}$. Therefore, workers who provide nursing care to users for the entire duration of the service ${ }^{(5)}$ are exposed to ionizing radiation. To carry out this work, professionals need to be trained and respect all radiation protection rules regulated by the Brazilian National Nuclear Energy Commission in Nuclear Norm 3.05(8), which guarantees practice safety for both professionals and users.

Thus, nursing workers in nuclear medicine (NM) have reduced freedom in work organization considering the excess of rigid norms that permeate work with ionizing radiation, a fact that can potentiate psychic loads. The importance of analyzing the psychological exhaustion experienced by nursing professionals in NM is in the fact that psychic burden results from dissension between the prescribed work - that ordered by work organization, which uses legal and formal parameters of work in NM, and the real, which refers to a person, his or her subjectivity, desires and different ways of knowing how to do $\mathrm{d}^{(3,9-10)}$.

Dejours ${ }^{(11)}$, since his initial studies, points out the connection between the body and the workers' psychic system. In this perspective, Psychodynamics of Work (POW) seeks to understand the subjective relationships between man and work, having in the organization and conditions of work one of its main focuses. These elements, according to Dejours ${ }^{(1)}$, can be responsible for mental disorders and exhaustion when the relationship with workers is unbalanced. In other words, when workers experience stressful situations, repetitive and/or mechanized activities, high demand for work, inadequate work conditions, among others, which can favor mental illness $s^{(3,10-12)}$.

Studies related to exhaustion experienced by health workers have increased, especially when it comes to nursing professionals, due to constant exposure to workloads and also due to the nature of work itself, when, many times, they dedicate themselves to taking care of others and forget to take care of themselves ${ }^{(13-16)}$. In NMS, exhaustion is inherent to professional practice due to occupational exposure to ionizing radiation, which requires specific knowledge of radiological protection. In this perspective, two situations that generate psychic workloads are pointed out: insecurity regarding professional practice and the recurring confrontation of situations of doubt due to lack of training; weakness in knowledge about the damage related to exposure to ionizing radiation ${ }^{(5)}$.

Thus, the study is justified by the role assumed by nursing professionals in NMS and the psychic aspects related to the nature of their work, which is expanding in Brazil. The results of this research will allow to know the setting regarding exhaustion of nursing workers working in NMS, so that it is possible to restructure the organization and work management, in order to minimize exposure to workloads. Considering the above and considering the aforementioned justification, the following guiding question was established: what are nursing workers' perceptions in NMS regarding exhaustion arising from psychic workloads?

\section{OBJECTIVE}

To analyze the psychic exhaustion experienced by nursing workers in nuclear medicine services.

\section{METHODS}

\section{Ethical aspects}

The research followed the ethical precepts of the Ministry of Health Resolution 466 of 2012. After research approval by the Research Ethics Committee with Human Beings and the signing of the Informed Consent Term, data collection has started. Participants' confidentiality and anonymity were guaranteed throughout the study, especially regarding the method of data analysis, since Collective Subject Discourse (CSD) represents workers' discourses and does not reflect isolated statements. At the end of each speech, an acronym followed by a number representing collective speeches organized in the sequence in which they appear.

\section{Type of study}

The research followed the COREQ precepts, since this is a qualitative study. The development of this was guided by the methodological assumptions of Dejours' POW.

\section{Methodological design and study setting}

In its first stage, POW assumes that in order to conduct a survey, it is necessary to identify a demand that must come from workers, whether in an isolated, collective or in groups ${ }^{(1)}$. This 
phase is called pre-research; in this case, an attempt was made to approach the object of study by identifying the workloads to which these professionals are exposed during work in $\mathrm{NM}^{(5)}$. Considering the predominance of psychic workload, this was chosen as the foundation of this investigation.

To choose the services, the following inclusion criteria were adopted: geographical proximity to the researcher and health services that offer similar procedures, resulting in two services located in southern Brazil. Both services perform NM diagnostic and therapeutic procedures, the difference is that private service offers Positron Emission Tomography - Computed Tomography (PET-CT) procedure, which requires specific, high-tech and stateof-the-art equipment, which is not yet available in the public service surveyed. Both the private service and the public service work in two-day shifts, with only iodotherapy hospitalizations as a 24-hour hospitalization service. However, professionals working in iodotherapy were excluded from the study due to the fact that services have different organizational and functioning characteristics regarding this therapy, which would make the method unfeasible. Thus, it was decided to briefly describe the existence of hospitalization for iodine therapy, since it appears in participants' speeches, since dose administration is performed by the group of workers surveyed.

\section{Data source}

To choose all participants, the intentionality criterion was used, including all nursing professionals from both services surveyed, totaling 12 ad hoc workers. The term ad hoc refers to the group of professionals who experience work. According to Dejours ${ }^{(1)}$, this nomenclature is used when, in the work process, the focus is not on who is the spokesperson for the situation, but on the reported situation. The collective was composed of 4 professionals with higher education (nurses) and 8 professionals with secondary education (nursing technicians). Of these, 9 are female and 3 are male. The workload of each service is very different, with the public service professionals working 24 hours a week, while in the private service the workload is 36 hours for healthcare professionals and 40 hours for nurse managers. Half of these workers (6) have another job, which varies from 30 to 44 hours per week, with an average of 35 hours per week.

\section{Period, data collection and organization}

Data collection took place from July 2015 to January 2016, and followed the methodological steps of POW: non-participant observation; individual interviews; collective interviews with the group of ad hoc workers in each service; press conference with the group of ad hoc workers from both services surveyed. All stages were conducted and developed by the main researcher. The observation took place on different days and shifts, lasting 80 hours, focusing on getting to know the work organization as a whole, observing what is done, how it is done and what it is done for. All observations were recorded in a specific instrument called an observation diary, which sought to identify activities in the following aspects of work: environment; professionals; conditions and division of labor; interprofessional relationship; procedures performed; hours/working hours/work schedules; in addition to checking for individual monitoring, use of personal protective equipment and assessment of potential activities that contribute to workers' exhaustion.

In the second stage, the individual interviews followed a semistructured script, developed from the aspects identified in the observation diary. This script sought to understand the dynamics and work organization, as well as allowing listening to workers' perceptions of their own work, recognizing issues related to the exhaustion of their health. The time for each interview was individualized, considering the needs of each participant, with a maximum duration of one hour.

Collective interviews with the group of ad hoc workers in each service took place after the initial interpretation of all speeches expressed in the individual interviews, seeking to confirm or refute the facts observed during the observation period. To this end, two meetings were held in the format of a conversation round, one in each service surveyed, lasting approximately one and a half hours, in which the themes from the first analyzes were presented to workers who held a debate until reaching a thought that reflected the reality of the collective. Finally, the group of ad hoc workers from both services surveyed came together to validate the final analyzes that were presented by the researchers. All four stages of the research took place over a six-month period. Individual and collective interviews took place at the service itself, according to workers' availability. The meetings were recorded using a digital recorder, and then all the lines were transcribed in full.

\section{Data analysis}

Considering that the POW is based the understanding the comments verbalized by workers and the importance is on consensual themes of workers' discourse, and not on who gave the speech, the CSD of Lefevre and Lefevre was adopted as a method of data treatment and analysis ${ }^{(17)}$. CSDs "are individual opinions that, when they pass through the analytical sieve of the researcher, [...] result in a construct, an artifact, a systematic description of reality and a reconstruction of collective thinking as a scientific product"(17). In CSD, based on individual speeches, we seek to reconstruct a single discourse that contemplates the collective representation about a certain phenomenon.

To assist in data organization and analysis, the software QualiQuantSoft ${ }^{\circ}$ was used, which organizes the methodological figures formulated by the creators of the method: key expressions, central idea, anchoring (not mandatory) and CSD itself. With the exception of anchoring, all methodological figures were carefully systematized in this research, and the meaning of the speeches analyzed was described considering the correlation between key expressions and central idea with non-participant observation ${ }^{(18)}$.

During analysis of the collected data, it was observed that the psychic burdens arising from the nursing work in NMS are important sources of psychological distress for these workers. The interaction of psychic loads intrinsic in the nature of nursing work and the consequences of these loads on workers' body contemplate The nursing setting in nuclear medicine services and the implications for workers' psychological exhaustion, the first category presented. Furthermore, there was a direct relationship 
between the psychological exhaustion agreed by the workers surveyed with Working conditions and relationships between users of care, which configured the second category of analysis.

\section{RESULTS}

\section{The nursing setting in nuclear medicine services and the implications for workers' psychological exhaustion}

The procedures in NMS involve the steps: planning; user orientation and preparation; injection of radiopharmaceutical and provision of care; monitoring, guidance and user release after the exam. In the services surveyed, the provision of nursing care occurs before, during and after each of these steps. The dynamics are related to user care and embracement and it is the responsibility of the nursing staff, added to the routine of working with ionizing radiation, which requires constant care, vigilance and prudence to ensure safety of themselves and users. The following is a CSD on the perception of exhaustion in NMS:

With the presence of radiation, I always consider the work environment a stress, I believe that the scale and the workload is a little excessive, we work hard, not only because we work all day, but in relation to radiation exposure. Physical tiredness is not as heavy as mental and emotional tiredness [...]. Stress is great, nursing has an important role in nuclear medicine, the whole staff can be late because of our work. We talk to the patient all the time, explain all the time, pay attention all the time and demand it all the time. This creates stress, self-demanding and irritability. We are extremely important and the lack of knowledge in nuclear medicine weakens our work, impacts and erodes health. All these situations together generate stress, and this interferes with social and family experience, sometimes even leisure you end up depriving yourself because of that ... when you get home, the desire is to stay thrown, doing nothing, but not I can because I still have house activities to do. (CSD 1)

During observation, it was identified that nursing professionals perform numerous activities at the same time, being requested all the time by users, companions or other staff members to perform activities. The non-flexible schedule puts pressure on workers to perform a job without errors. The dynamics of service cannot be delayed, nor can it waste radioactive material that has a short activity time (decay), so the synergy between preparation, injection of the radiopharmaceutical and the examination must be perfect, or the radiopharmaceutical will not have the effect desired and the procedure will need to be cleared.

It is identified a difficulty on the part of workers in using defensive mechanisms, especially those related to time away from work, as seen below:

Working two jobs is very tiring, after a day of work I feel stressed, with leg pain and even no appetite. I sleep and rest very little, I believe that if I had only one job, I would not feel all of this, but I cannot support the family with one job. Therefore, the valuation should be better, for the responsibility that we have, for the work that we do, if the salary was better I could have only one job. (CSD 2)

CSD 1 and 2 show that there are two conditions in the nursing work in NM that deserve attention. The first is related to gender issues in activities outside of work, since the majority of workers are female, and the second condition refers to the increase in psychological exhaustion arising from the need for other employment relationships.

\section{Psychic exhaustion of workers resulting from working conditions and relationships with users of care}

In the collective of workers surveyed, suffering was perceived before work that needs to be done, but it is not done in the way that professional idealizes and believes to be what users deserve, given that working conditions are unfavorable.

If you don't have the ideal equipment, you don't have space to place the patient, you don't have space for a stretcher because the place is small, it all gets stressful. [...] it is very bad to provide guidance to the patient and the other patient on the side will also listen and interpret differently or be afraid of the exam. If you have a complication it is difficult to attend and this situation creates insecurity for workers. Moreover, the physical space is very restricted. Sometimes, everything is very crowded and accidents happen. The other day, a member of the staff ran into another colleague and all radioactive material fell on the floor and in her apron. This is very bad and all these situations make me stressed. (CSD 3)

In CSD 3, there is insecurity and anxiety in the face of the situations they face, since user and work assistance are compromised by working conditions. This causes work activities to be performed in a way that does not meet workers' social and professional purposes and principles, generating stress and even ethical suffering. Data from the observation showed that both services have an accelerated work rate, with a lean staff and a high demand for procedures. This can cause an increase in the episodes of occupational accidents, as reported in CSD 3 and witnessed by the researcher, either by not using personal protective equipment, by workers focusing on several activities at the same time or by the need to perform the task in a short interval time, thus compromising the correct and safe performance of tasks.

It was found that the psychological exhaustion of workers originates from the work of different workloads on workers' body. One such charge is physics, exposure to ionizing radiation. Using this work tool ends up haunting the psyche of this professional, especially when working conditions hinder the prevention of accidents. Workers recognizes that the work activity they perform has risks, admitting the possibility of some physical disorder in the future:

\begin{abstract}
Due to radiation, I believe that I will suffer something later, we know that the risk of cancer is greater for those who are exposed to radiation. [...] as for nuclear medicine, I feel insecure, if I'm doing something wrong and especially about radiation, I don't know to what extent it harms me or not, in the long term or in the short term, if I got infected... these days I got contaminated and I was afraid to bathe my daughter [...] every place we walk during work has radiation exposure. Despite all that, I like what I do. (CSD 4)
\end{abstract}

From the results, it was realized that the collective of workers has fear and uncertainty regarding the work with ionizing radiation and its impacts on health. Even though every group has undergone some training, exposure to ionizing radiation is 
inherent in the exercise of the profession. The physical charge of ionizing radiation has a great influence on the production of other workloads. Psychic charges related to fear are noteworthy, since the effects of ionizing radiation in NMS, for the most part, are stochastic.

It was found that social work relationships can cause danger to workers' mental balance. This fact is materialized in workers' speeches transcribed below, when they report the difficulty in providing care to users diagnosed with cancer or even pediatric users. It should be noted that these difficulties were not only expressed verbally, but also in moments of long silence between lines, during pauses to take a deep breath and reestablish control over emotions and even the expression of suffering through crying:

Sometimes, the exhaustion is great, there are days when I feel tired and sad because we put ourselves in the shoes of the person being assisted. We work with cancer patients; they are children and adults diagnosed with a tumor and this affects emotionally. Patients with a history of cancer usually have difficult venous access, often it takes time to be able to perform the puncture, delays the entire schedule, this creates a lot of stress because I need to offer comfort to this patient and at the same time continuity of the procedure depends on me, psychological exhaustion is great. Whether you like it or not, you end up depressed because it affects the emotional side a lot. Despite that, there are days when I feel happy. (CSD 5)

The duality between suffering and pleasure is evident in nursing work in NMS, at the same time that it is necessary to mobilize technical knowledge; professionals also need to make use of empathy and mutual affection. Making use of these subjective tools exhaust workers, since they are a social being who also has family, friends, problems and is susceptible to developing the diseases that are treated in their work. Based on the aforementioned CSDs, this study confirms the influence of work organization as an element that enhances or facilitates exhaustion on workers, since exposure to loads and, consequently, exhaustion depend directly on the task's content, workloads, as well as pace, conditions and working hours.

It should be noted that, among the services surveyed, only the public service had the occupational health sector and the radiological protection sector. The presence of these services focused on workers contributes to making them feel safer to carry out their activities, in addition to promoting and supervising using radiological protection mechanisms. The importance of a support network is evidenced, formally structured by the health institution for monitoring and assisting workers' health.

\section{DISCUSSION}

From the results obtained, it appears that nursing workers in NMS are exposed to physiological, physical, chemical, biological and mechanical loads, as well as professionals from other sectors of health services ${ }^{(4)}$, which interfere with psychological exhaustion, this strongly subjective. In this perspective, the mental fatigue, stress and self-recovery previously mentioned in CSD 1 arise mainly from NMS' characteristics. It is important to highlight that the physical and emotional responses pointed out can be characterized as occupational stress. In this condition, professionals are more likely to develop several health problems. Consequently, there is an increase in the rate of absenteeism in institutions and professional dissatisfaction ${ }^{(19)}$. Dejours ${ }^{(1)}$ is categorical when stating that suffering is a result of work organization and that individuals with the most dense psychological structure can be victims of mental stress induced by work organization. Different studies show that, in order to reduce psychological exhaustion, one must avoid the accumulation of too many tasks, i.e., avoid or reduce exposure to workloads, perform physical and leisure activities, in addition to healthy habits and family and social life ${ }^{(14-16)}$.

Two works, reported by CSD 2, reflects the precarious working conditions of current capitalism, revealing, in general, low remuneration of the category ${ }^{(13)}$. A recent survey carried out across the country ${ }^{(20)}$ points out the existence of wages for the nursing staff working in the public, private and philanthropic sectors, with an average monthly income of up to $\mathrm{R} \$ 1,000.00$ (reais is Brazil's currency) for $15.8 \%$ of the workforce. between $\mathrm{R} \$ 1,001.00$ and $\mathrm{R} \$ 2,000.00$ for $30 \%$ of the workforce. The same survey revealed that $32.6 \%$ of the Brazilian nursing workforce has 2 or 3 jobs. Still on this topic, a study by the Pan American Health Organization ${ }^{(21)}$ shows that this practice affects quality of care.

As reported by CSD 2, salary represents a form of recognition for the work performed, which can have negative meanings. For Dejours $^{(1)}$, the financial remuneration of workers has different meanings, concrete and abstract. Among the concrete meanings is family support, acquisition of material goods, payment of debts, among others, and it is mentioned that dreams, fantasies and projects of realization refer to the abstract meanings of remuneration. CSDs show that lack of recognition is an important factor in the manifestation of workers' psychological exhaustion ${ }^{(3)}$, especially when added to the high pace of work and the demand in the specialty of care. Therefore, it is necessary for health institutions to use mechanisms that contribute to make workers feel valued and, above all, to be able to signify the task's content they perform ${ }^{(11)}$, since recognition exerts "a great influence on the construction of identity and mental health, transforming suffering into" pleasure related to the strengthening of identity"(11).

In relation to psychic loads related to gender, it should be noted that women represented $75 \%$ of the workforce in the services surveyed, which corroborates the data of the research carried out by Machado ${ }^{(20)}$. Machado found that the Brazilian nursing workforce consists of $85.1 \%$ of female professionals. Generally, women perform repetitive and tiring tasks that can lead to physical and mental illness, since they feel overwhelmed by tasks that are not sources of pleasure ${ }^{(14)}$, especially regarding two and, often, three works performed by these professionals in time outside of work organization. About this, Dejours ${ }^{(22)}$ states that, from a psychic point of view, it is impossible to separate work and extra-work and that, when the relationship with work is not healthy, exhaustion in the private space arise, potentiating the physical and mental breakdowns of female workers.

The ethical issues pointed out by CSD 3 generate psychic workloads that reflect suffering for workers, when they need to make decisions that disrespect their ethical sense ${ }^{(23)}$. The sum of ethical and psychological suffering can represent exhaustion, such as stress and demotivation. Lack of adequate space and equipment was a problem reported in a survey conducted in four 
countries in Latin America, including Brazil ${ }^{(21)}$. A national survey highlights that only $5.3 \%$ of nursing workers in public services and $14.6 \%$ of workers in private services consider working conditions to be excellent ${ }^{(20)}$.

Another workload pointed out by CSD 4 is the physical risks related to exposure to ionizing radiation. A study carried out with NM workers in services in Kuwait found that the nursing staff has higher rates of radiation exposure in the hands, fingers and whole body than the rest of the staff(24). This is mainly due to the nature of nursing work, which carries out its activities for a long time and is very close to users. In Brazil, a study ${ }^{(5)}$ observed that the greatest obstacles experienced by nursing professionals in NMS are linked to understanding the phenomenon of ionizing radiation and the correct methods of protection.

Concerning the fear pointed out in Dejours speeches ${ }^{(1)}$, this is part of workers' experience due to the exposure to workloads that represent physical or even psychological exhaustion (physical and psychic integrity). The workloads attributed to this fear are generally inherent to the nature of work, they are often part of the collective work, with incomplete prevention of work organization because total exhaustion is generally poorly known. As an example, the need for continuing education is cited, which would help workers to act with more awareness and security. Regarding fear and ignorance about the future risks of exposure to ionizing radiation, the authors ${ }^{(5)}$ observed that the greatest obstacles experienced by nursing professionals in NMS are linked to understanding the phenomenon of ionizing radiation and the correct methods of protection. Dejours ${ }^{(1)}$ highlights that the mental exhaustion resulting from psychic workloads inherent to work considered dangerous is still little explored and states that this fact, "besides being a fear multiplication coefficient, also increases the mental or psychic cost of work"(1).

However, still in CSD 4, it is possible to see mobilization of defense mechanisms when they report "[...] despite all this, I like what I do". Dejours ${ }^{(1)}$ corroborates stating that fears are contained in defense mechanisms and rarely come to the fore, but that if it were not so, workers would be unable to perform their tasks. The awareness at all times of the dangers and risks of work developed would make an individual need to take so many precautions that he or she would become unproductive. There is an ambiguous relationship in the defense mechanisms, while protecting workers against psychological exhaustion, preventing the change in the reality that causes exhaustion. Fact is that fear devastates the mental health of workers gradually and inevitably ${ }^{(1)}$.

Corroborating CSD 5, a survey ${ }^{(13)}$ carried out in an oncology unit found that nursing professionals suffer in some way from emotional exhaustion, especially with feelings of sadness, anxiety, pity and helplessness. In NMS, relationships that are established in the world of work can hinder the development of tasks, creating an environment where suffering becomes the product of that work process ${ }^{(9)}$.

In the aspect of POW, considering the work relationships experienced by nursing professionals in NMS, especially regarding the aspect of emotional involvement with users, it is possible to state that there are no means to separate the social subject from the working subject, i.e., workers are constituted through the experiences lived by work ${ }^{(1,9)}$. It is also through work that an individual is able to transform suffering into pleasure, giving work activity a new meaning, as evidenced in the excerpt "[...] despite this, there are days when I feel happy" (CSD 5). Subjective mobilization, the reframing of work and its social importance contribute to overcoming suffering, giving rise to creative suffering.

In the collective speeches, there was a predominance of aspects related to insecurity regarding their work practice, either due to the fragile knowledge about radiological protection measures or even fear related to exposure to ionizing radiation. Exhaustion can be mitigated by adopting continuing education practices. Training/continuing education must be present in the different health settings, incorporated in the performance of nurses and other professionals who are part of a staff, with the aim of providing significant changes in professional practice ${ }^{(25)}$.

For Dejours ${ }^{(1)}$, work is living together and goes far beyond producing or performing tasks. Working, in the subjective sense, is an opportunity to listen and develop trust and affective/social relationships, in addition to building the real meaning that work transcends prescribed work and is not limited to norms. Affective relationships in NMS care can influence workers' satisfaction, pleasure, quality of life and mental health, in addition to care quality and safety, and these experiences can favor pleasure in nursing praxis. Aiming at professional well-being, it is necessary that health managers develop actions in order to promote and protect the mental health of these workers, through policies that consider the peculiarities of work activity ${ }^{(26)}$.

\section{Study limitations}

The performance of this study in two NMS in the same municipality, first with a relatively small number of workers, may represent a limitation, but it does not compromise the generalization of results, since $50 \%$ of nursing workforce in the state NMS was represented in this study. In addition, contrary to expectations, it was not feasible to validate data with the collective of workers from both institutions at a single time. Due to difficulties in the subjects' participation, data validation had to be performed in each service. However, although they are heterogeneous institutions, with different ways of organizing work, the nature of work and the professional category are homogeneous, which does not invalidate the study, even allowing to rethink these exhaustion in other NMS.

\section{Contributions to nursing, health, and public policies}

The results presented in relation to the psychological exhaustion of workers in NMS are relevant, especially for this information to be used to propose preventive and corrective actions in NMS, seeking to promote and protect the health of workers and users who undergo procedures in NM. Moreover, the research showed the need for regulation by the class bodies focused on assignments, workload and staff sizing, so that these professionals can act safely in the specialties that use radiological technologies. Through this regulation, it is believed that it is possible to improve working conditions, salary remuneration and reduce double employment relationships, which would directly impact improvements in workers' health. 


\section{FINAL CONSIDERATIONS}

Psychological exhaustion experienced by nursing workers in NMS originates mainly in the three dimensions of work organization: organization itself, working conditions and relationships, which can compromise the quality of care provided and workers' quality of life. In all these dimensions, there are workloads that act significantly with workers' body and mind, potentiating psychological exhaustion. Therefore, it is essential that NMS organize themselves in order to minimize exposure to workloads, providing better working conditions, greater autonomy and leadership to workers, in addition to offering spaces for listening and support to the collective of workers.

In this perspective, the institution will be able to use management tools that value the subjectivity of health work, since it is a work closely dependent on workers themselves, biopsychosocial beings with their desires and limitations that need to harmonize technical work with the delicacy of the act to take care of. Proposing participatory management instruments that understand this duality of nursing work in NM is essential for building a creative, autonomous, flexible and safe organizational environment.

The study allows us to understand that the person who works also lives socially. Therefore, maintaining workers' psychic health is important, since it will directly impact work organization, quality and productivity. This conception must also be prioritized by workers. Moreover, continuing education must be applied, as it helps workers to recognize these loads, avoid them and expose themselves to them consciously, which makes it possible to act safer, especially encouraging workers to use all radiation protection means.

\section{REFERENCES}

1. Dejours C. A Loucura do Trabalho: estudo da psicopatologia do trabalho. 6th ed. São Paulo: Cortez; 2015.

2. Felli VA, Baptista CP. O contexto do trabalho de enfermagem e a saúde do trabalhador. In Felli VA, Baptista PCP. Saúde do trabalhador de enfermagem. Barueri: Manole; 2015:1-19.

3. Sousa J, Santos ACB. A psicodinâmina do trabalho nas fases do capitalismo: análise comparativa do taylorismo-fordismo e do toyotismo no contexto capitalismo burocrático e do capitalismo flexível. Rev Ciên Adm. 2016;23(1):186-216. doi: 10.5020/2318-0722.23.1.186-216

4. Carvalho DP, Rocha LP, Pinho EC, Tomaschewski-Barlem J, Barlem LD, Goular L. Workloads and burnout of nursing workers. Rev Bras Enferm. 2019;72(6):1435-41. doi: 10.1590/0034-7167-2017-0659

5. Melo JAC, Gelbcke FL, Huhn A. Nursing workloads in nuclear medicine. Rev Enferm UFPE. 2017;11(3):1279-88. doi: 10.5205/ reuol.10544-93905-1-RV.1103201719

6. Ministério da Saúde (BR). O SUS de A a Z: Garantindo a saúde dos municípios[Internet]. 3rd ed. Brasília: Ministerio da Saúde. 2009[cited 2020 Jan 30]. Available from: http://bvsms.saude.gov.br/bvs/publicacoes/sus_az_garantindo_saude_municipios_3ed_p1.pdf

7. Ministério da Ciência, Tecnologia, Inovações e Comunicações (BR). Glossário de Termos Usados em Energia Nuclear [Internet]. 2020[cited 2020 Feb 06]. Available from: http://www.cnen.gov.br/noticias/documentos/glossario_tecnico.pdf

8. Ministério da Ciência, Tecnologia e Inovação (BR). Comissão Nacional de Energia Nuclear. CNEN NN 3.05 - Requisitos de radioproteção e segurança para serviços de medicina nuclear. [Internet]. 2013[cited 2020 Jan 30]. Available from: http://appasp.cnen.gov.br/seguranca/ normas/pdf/Nrm305.pdf

9. Lavnchica GRFS. A clínica psicodinâmica do trabalho: teoria e método. Khóra Rev Transdiscip [Internet]. 2015[cited 2020 Jan 30];2(2):1-17. Available from: http://site.feuc.br/khora/index.php/vol/article/view/45

10. Abdoucheli E, Dejours C, Jayet C. Psicodinâmica do trabalho: análise da relação prazer, sofrimento e trabalho: contribuições da Escola Dejouriana à análise da relação prazer, sofrimento e trabalho. São Paulo: Atlas; 1994.

11. Dejours C, Barros JO, Lancman S. A centralidade do trabalho para a construção da saúde. Rev Ter Ocup USP. 2016;27(2):228-35. doi: 10.11606/issn.2238-6149.v27i2p228-235

12. Lancman S, Sznelwar I. Chistophe Dejours: da psicopatologia à psicodinâmica do trabalho. 2nd ed. Brasília: Fiocruz; 2008.

13. Kolhs M, Olschowsky A, Barreta NL, Schimerfening J, Vargas RP, Busnello G. Nursing in urgency and emergency: between the pleasure and suffering. Rev Pesqui: Cuid Fundam. 2017;9(2):422- 31. doi: 10.9789/2175-5361.rpcfo.v9.5427

14. Ferreira KS, Medeiros SM, Carvalho IM. Psychical distress in nursing worker: an integrative review. Rev Pesqui: Cuid Fundam. 2017;9(1):25358. doi: 10.9789/2175-5361.rpcfo.v9.3912

15. Muñoz Al, Valásquez MS. Síndrome de quemarse por eltrabajo enprofesionales de enfermaría de los servicios de urgencias y de unidad de cuidado intensivo de tres hospitales de Bogotá. Rev Fac Nac Salud Pública. 2016;34(2):202-11. doi: 10.17533/udea.rfnsp.v34n2a09

16. Rosado VM, Russo GHA, Maia EMC. Produzir saúde suscita adoecimento? As contradições do trabalho em hospitais públicos de urgência e emergência. Ciência saúde coletiva. 2015; 20(10): 3021-32. doi: 10.1590/1413-812320152010.13202014

17. Lefevre F, Lefevre AMC. Discourse of the collective subject: social representations and communication interventions. Texto Contexto Enferm. 2014;23(2):502-07. doi: 10.1590/0104-07072014000000014

18. Flor RC, Melo JAC, Gelbcke FL, Ramos FRS, Amadigi FR. Investigação da práxis em enfermagem radiológica: aplicação da metodologia da psicodinâmica do trabalho. 2017;26(3):e0930017. doi: 10.1590/0104-07072017000930017 
19. Santana LC, Ferreira LA, Santana PM. Occupational stress in nursing professionals of a university hospital. Rev Bras Enferm. 2020;72(2):e20180997. doi: 10.1590/0034-7167-2018-0997

20. Machado M, Aguiar Filho W, Lacerda WF, Oliveira E, Lemos W, Wermelinger M, et al. Caracteristicas gerais da enfermagem: o perfil sócio demográfico. Enferm Foco. 2016;7(Esp):11-17. doi: 10.21675/2357-707X.2016.v7.nESP.686

21. Organización Panamericana de la Salud. Estudio comparativo de las condiciones de trabajo y salud de los trabajadores de la salud en DC: OPS. Washington: Organización Panamericana de la Salud e Organización Mundial de la Salud. [Internet]. 2012[cited 2020 Jan 30]. Available from: http://renastonline.ensp.fiocruz.br/recursos/ estudio-comparativo-las-condiciones-trabajo-y-salud-los-trabajadores-la-salud-en-argentina

22. Dejours C. Psicodinâmica do trabalho: casos clínicos Porto Alegre: Dublinense; 2017.

23. Dejours C. A banalização da injustiça social. 7th ed. São Paulo: Fundação Carlos Chagas; 2007.

24. Alnaaimi M, Alkhorayef M, Omar M, Abughaith N, Aldouij M, Salhudin T, et al. Occupational Radiation Exposure in a Nuclear Medicine Department in Kuwait. Rad Phys Chemistry. 2017;140: 233-6. doi: 10.1016/j.radphyschem.2017.02.048

25. Lavich CRP, Terra MG, Mello AL, Raddatz M, Arnemann CT. Ações de educação permanente dos enfermeiros facilitadores de um núcleo de educação em enfermagem. Rev Gaúcha Enferm. 2017;38(1):e62261. doi: 10.1590/1983-1447.2017.01.62261

26. Santos F, Brito FSFM, Pinho L, Cunha F, Rodrigues Neto F, Fonseca DG, et al. Common mental disorders in nursing technicians. Rev Bras Enferm. 2020;73(1):e20180513. doi: 10.1590/0034-7167-2018-0513 